\title{
The Call for a New Ecoreligion
}

Morning has broken like the first morning,

blackbird has spoken like the first bird.

Praise for the singing, praise for the morning, praise for them springing fresh from the Word!

Norwegian book of hymns, Hymn $80 \mathrm{I}$.

"Nature is the true religion for Norwegians. Our gods are named the Mountain, the Plateau, the Ocean." I There is some truth to this saying, which has its origin in a comment by the peace researcher Johan Galtung. In Norway it is normal for even devoted Christians to skip Sunday church in favor of a nature walk or cross-country skiing. And when attending church, the faithful often sing hymns filled with nature metaphors. The believer's gaze of knowing the source of goodness may come from the gospel, but it may also come from pristine nature as the nation's spiritual life takes place outdoors in scenic environments rather than inside buildings. The Deep Ecologist Arne Næss was no exception. He looked at the Hallingskarvet Mountain, where his own cabin was located, as a religious force. To him technical "climbing was hailing and pilgrimage" to the mountain, as Hallingskarvet to him had the status of "what one in the mythology calls a god (deva), and fortunately a good one." ${ }^{2}$ His longtime

I Johan Galtung quoted in Niels Chr. Geelmuyden, Grepet $i$ Ord (Tjøme: eBokNorden, 20I4). Cf. Henrik Ibsen, Brand, I 867. Eleanor Farjeon, "Morning has broken," in Norske salmebok (Bergen: Eide forlag, 2013), hymn 801, p. 920.

2 Arne Næss, "Klatrefilosofiske og biografiske betraktninger," Mestre fjellet, I7, no. I6 (I975), I7-I6. 
collaborator Per Ingvar Haukeland articulated a similar sentiment in his book Himmeliorden (Heavenly Earth, 2009) framed on his Quakerinspired beliefs. ${ }^{3}$

How are we to understand this religious point of view? And how did environmentalists engage and utilize religious language and traditions when speaking about the environment? Fortunately, historians of religion have partly answered this question by showing that ecologically informed ethics and politics often invoke the language of religion when making their points. The historian Mark S. Stoll, for example, has shown that the rise of American environmentalism owes a great deal to Christian religious traditions. ${ }^{4}$ The case is similar to Norwegian environmentalism, which, according to Tarjei Rønnow, represents a "new pietism" invoking age-old Lutheran values, rituals, and systems of belief when seeking to "save nature." What has yet to be understood are the historical details of how and why environmentalists came to adapt religious language, and how theologians responded. This chapter will review this process in some detail, arguing that the Deep Ecologists were instrumental in giving the Church of Norway the ecological focus it has today.

The Evangelical Lutheran Church of Norway, it is worth noting, is a state church in which roughly eighty percent of Norwegians are registered members. The other twenty percent of people in the country consists mostly of non-believers, and tiny groups of Catholics, Quakers, Jews, Buddhists, Muslims, and Norse pagans. Internationally, the Church receives its chief intellectual support through its membership in the Lutheran World Federation and the World Council of Churches. The King, the Prime Minister, and the majority of the Cabinet Ministers were, as official leaders of the Church, obliged to profess Lutheran faith, making the Church the all-dominating force in Norwegian religious life. It is a fairly democratic institution in which representatives of the parishes, deaneries, and dioceses elect the General Synod, which has the National Council as its executive body. This organizational structure has, as will be apparent, consequences for the way in which ecological

${ }_{3}$ Per Ingvar Haukeland, Himmeljorden: Om det av Gud i Naturen (Oslo: Kvekerforlaget, 2009).

${ }^{4}$ Mark S. Stoll, Inherit the Holy Mountain: Religion and the Rise of American Environmentalism (Oxford: Oxford University Press, 201 5 ).

5 Tarjei Rønnow, "Takk gode Gud for moder jord, hun gjør oss ett med alt som gror: Religiøsitet og miljøengasjement i Norge," Norsk antropologisk tidsskrift, I5 (2004), I 8-3I; Saving Nature: Religion as Environmentalism, Environmentalism as Religion (Münster: LIT Verlag, 20II). 
thinking could spread within the Church. How did it respond to the ecocrisis? The attempt to save the Mardøla River from hydropower development in the summer of 1970 was the issue that brought ecological concerns to the public forefront in Norway. How did the Church react to the arguments expressed by vocal Deep Ecologists trying to save the river? These activists began a fierce public debate about nature conservation, focusing on human attitudes to the natural world. As a result, no public institution of moral importance could avoid taking a stand on ecological issues, especially the Church.

The issues at stake were not only about development of rivers, but also about industrialization, human population growth, and pollution. As will be argued, the Deep Ecologists' questioning of economic growth, technocracy, and industrialism appealed to many theologians, who often also sympathized with the Deep Ecologists' endorsement of outdoor life, rural communities, and modest lifestyles. This chapter will review early attempts by theologians and some key lay believers to incorporate ecological perspectives and beliefs into the Church. For them, environmentalism represented an opportunity to revive the Church's pietist Lutheran doctrine among the young and thereby mobilize a new audience. This chapter will first point to the role of religion among ecophilosophers and biologists, as it was within this group that the first Norwegian eco-theological thinking emerged. The subsequent sections will show how the Church responded by endorsing the ecoreligious perspective.

\section{DEEP ECOLOGY AND RELIGION}

In I97I Lynn White's article "The Historical Roots of Our Ecologic Crisis" appeared for the first time in Norwegian. ${ }^{6}$ In this article the medieval historian accused Judeo-Christian theology of nurturing an exploitative ethic toward the natural world. The anthropocentric domination of nature was at the core of the Bible's message, according to White, as it states that humans were formed in God's image and thus are superior to the rest of the world. The article had originally appeared in Science in I967 and was thus well known among Norwegian ecologists following the international debate. The translation aimed at bringing White's

${ }^{6}$ Lynn T. White, “The historical roots of our ecologic crisis," Science, I 55, no. 3767 (Mar. I0, I967), I 203-7; translated into Norwegian as "Den økologiske krises historiske røtter," Naturen, 95 (I97I), 77-92. 
critique to a broader Norwegian audience, as it appeared in the popular science journal Naturen (Nature).

Most ecologists, environmental activists, and philosophers in Norway were non-believers. It is therefore not surprising that White's article was initially read as a contribution to the argument to weaken the role of religion in society in order to advance the ecological cause. Even though creationism never achieved any real weight in Norway, most scientists saw religion in opposition to science, as faith could not be mixed with ecological facts. ${ }^{7}$ There was also a wide mistrust of religion among leftleaning students, activists, and environmentalists who tended to agree with Karl Marx's famous saying that religion "is the opium of the people." Thus, many of the environmentalists would not include religion in their discussions of the eco-crisis, and White's arguments explained why. Instead, people hoped that ecological science in itself could be a substitute giving "aim and meaning" in a secularized world. ${ }^{8}$

Among the philosophically informed ecologists, there was a general uneasiness about this dominating tendency to exclude religious beliefs from the framework of analysis. In I972, a non-religious graduate student on the International Biological Program at the University of Oslo made a plea to end capitalism and establish a steady-state society based on eco-political principles by emphasizing the importance of moving beyond technological answers to the environmental crisis. ${ }^{9}$ This was an issue of nurturing belief in the power of environmental ethics and lifestyles, and increasing faith in the value of a radical moral change in human attitudes toward nature.

As shown in previous chapters, the importance of a moral stand against industrial technocracy was at the core of Deep Ecology. As a consequence, the ecophilosophers would look with hope and admiration upon those with a system of beliefs in tune with their ecological views. They would often make it clear that they were involved in a social movement within which people had different perspectives and reasons for why one should protect the environment. Thus, people with religious beliefs were welcomed to join the group as long as they were credible defenders of nature. Indeed, the difference between being a "deep" and a "shallow" ecologist depended on whether or not one went beyond mere

\footnotetext{
7 Arne Rønnild, “Gud og naturvitenskapen,” Tidsskrift for teologi og kirke, 48 (I977), I93-203.

${ }^{8}$ Lyngnes, "Kan biologisk kunnskap gjeve dei unge mål og meining med livet?"

9 Harald Olsen, “Mot en økopolitisk enhetsfront?" Kirke og kultur, 77 (I972), 397-405.
} 
technocratic or economic reasons for sheltering ecological complexity. The environmentalists within Norway's tiny Quaker group were particularly active in engaging with the Deep Ecologists by publishing articles and books on the importance of ecology to Christian spirituality. They also invited Kvaløy, Næss, and several other key members to voice their views in their Quaker journal. ${ }^{\text {IO }}$

Thus, the ecophilosophers recognized that religion could be a powerful ally for a common cause if its principles and practice showed respect for the environment. Though he wasn't strictly speaking a Deep Ecologist, Johan Galtung's statement at the $3 \mathrm{rd}$ World Future Research Conference in Bucharest in 1972 may illustrate this sentiment: "A nature without soul is easy to destroy; a nature with soul is one that invites partnership, respect, equilibrium." ${ }^{\text {I }}$ Issues related to God and ecology were debated at the Peace Research Institute in Oslo where Galtung was in charge. In I967 they hosted the first conference for the World Futures Studies Federation, and one of the topics discussed was the separation of humans, God, and nature in Christian thinking that allowed for and encouraged exploitation of the world's material resources. ${ }^{\mathrm{I}}{ }^{2}$ As a remedy, the peace researchers, including Galtung, pointed to the wisdom of Oriental thinking and religion.

There were several reasons behind Galtung and the Deep Ecologists looking toward the Orient for answers. Most generally, this region represented a viable alternative source of inspiration for those who refused to take a side in the Cold War deadlock. Galtung and Næss had (as discussed in Chapter 3) published a couple of books about Gandhi, which pointed toward his non-violent thinking as the key for unlocking tensions between communists and capitalists. In the process they also learned to appreciate Buddhism and the Bhagavad-Gita. This was not only an intellectual issue, as they, along with fellow ecophilosophers, visited India, Nepal, Iran, and Pakistan to draw inspiration from the region. The visit to Nepal and the village of Beding by Kvaløy, Nils Faarlund, and Næss in the summer of I97 I may illustrate this. The nearby mountain Gauri Shankar was considered holy and thus untouchable for the Sherpa living there, an approach to nature the ecophilosophers found impressive.

1o Hans Eirik Aarek, Kristendom og økologi (Ås: Kvekerforlaget, 1978). Arne Næss, "Grønn sosialisme," Kvekeren, 5 (I972), 7I-2. Sigmund Kvaløy, "Trenger mennesket uberørt natur?" Kvekeren, I (I973), 6-7.

II Galtung, "The limits to growth' and class politics," p. Iо8.

${ }^{12}$ Guttorm Gjessing, "Ecology and peace research," Journal of Peace Research, 4 (I967), I $25-39$. 
As technical climbers who had traveled to Beding to reach the peak of the mountain, they decided to abandon this aim in respect for Sherpa beliefs. This was a personal sacrifice and a learning experience for all of them as, from then on, they would abandon the view that climbing was about reaching mountain peaks. To Næss the belief in the holiness of the Gauri Shankar would serve as evidence of the power of religion as a source of resistance to the exploitation of nature. ${ }^{\mathrm{I} 3}$ Faarlund and Kvaløy would both express similar points of views. ${ }^{\mathrm{I}}$

These views raised important questions with respect to religion and science. In February 1972 the ecophilosophers gathered at a small seminar at Tømte Gård, a picturesque botanical Research Station near Oslo, to discuss the issue. The seminar was arranged by David Klein, an ecologist at the University of Alaska who was spending his sabbatical year at the University of Oslo from the fall of I97I to research reindeer, among other things. ${ }^{15}$ Among roughly thirty participants were, aside from Kvaløy and Næss, ecologists such as Ivar Mysterud, Eivind Østbye, and Eigil Reimers (b. 1939).

Næss gave the keynote lecture (which is lost). Judging from Klein's response it is likely that it was about ecology and the Bible, as the section of Næss's "Ecosophy T" that deals with this topic was written in this period. Here White's criticisms of Christian domination of nature served as his point of departure, though Næss would quickly turn to what he saw as a largely forgotten eco-friendly outlook on the Bible. Inspired by the studies of John N. Black and Clarence Glacken, among others, he pointed out that one could not judge the environmental friendliness of a person based on whether or not he or she believed in the Bible. ${ }^{16}$ Næss was not a believer himself, but saw Christians as potential allies for the emerging Deep Ecology movement. There was plenty of support for an ecological sensitivity in the Bible, he argued, and quoted several passages from both the Old and the New Testament to support his view.

I3 Arne Næss, "Skytsgudinnen Gauri Shankar: Appell om fredning," Mestre fjellet, I3 (I972), I 5 .

${ }^{14}$ Nils Faarlund, "Glimt fra klatringen på eggen," Mestre fjellet, I3 (I972), 9-IO. Sigmund Kvaløy Setreng, "Tseringma-hymnen og det hellige fjell Tseringma," in Sven Erik Skønberg (ed.), Grønn pepper i turbinene (Oslo: Universitetsforlaget, I985), pp. 8 I-4.

I5 Eigil Reimers, David R. Klein, and Rolf Sørumgård, "Calving time, growth rate, and body size of Norwegian reindeer on different ranges," Arctic and Alpine Research, I 5 (I983), I07-I 8 .

${ }^{16}$ Næss, Økologi og filosofi, 3rd ed., I60-8. John N. Black, The Dominion of Man: The Search for Ecological Responsibility (Edinburgh: Edinburgh University Press, I970). Glacken, Traces on the Rhodian Shore, 1967. 
Næss was not the only one at Tømte who saw religion as a source of insight for understanding the deeper meaning of ecology. Most active was Kvaløy who upon his return from his travels to Nepal became deeply fascinated by Buddhism and began in earnest to study the Bhagavad-Gita. It was especially the Tantric idea of a spiritual dimension to the web of life which fascinated Kvaløy, as it revealed "mother earth's treasures" and allowed an animistic view of nature's ecology. ${ }^{17}$ This was not only of academic importance to Kvaløy, as in this period he also began to practice Buddhism. Indeed, he would draw elaborate pictures depicting monks in Beding, meditating on the holiness of the mountain Gauri Shankar that, in his words, depicted a "reunion with the One that flows through the entire nature." ${ }^{18}$ As a charismatic leader of the ecophilosophy group, the Deep Ecology movement, and the Mardøla demonstrations, he was most definitely an authority among both students and nature protectors. That Buddhism could offer a way forward in understanding nature's rhythms and life on Earth raised interest and eyebrows among the concerned environmentalists.

At the Tømte seminar there were thus three competing answers to the question of the role of religion in environmentalism in response to White's criticisms of Christian domination of nature. The ecologists, including Mysterud and Østbye, thought the ecological debate would be better off if one stuck to ethical issues and kept religion out of the picture. Næss, on the other hand, thought that potential allies for the Deep Ecology movement could be gained by mobilizing a more humble human caretaker role from the Bible, while Kvaløy abandoned the Christian heritage altogether in favor of Buddhism.

Coming from the University of Alaska, Klein found ecophilosophy to be a new intellectual territory. On the one hand, he was fascinated and flattered by the philosophers taking an interest in his lectures on wildlife ecology and management as well as his collaborative research on wild reindeer with Reimers. On the other hand, he saw a flight from reason in religious adaptations of ecology. At Tømte he asked the audience:

${ }^{17}$ Sigmund Kvaløy, "Mother Earth's treasures and their revealers," in Padma Tshewang, Phuntsok Tashi, Chris Butters, and Sigmund Sætreng (eds.), The Treasure Revealers of Bhutan (Kathmandu: Bibliothecha Himalayica, I995), pp. I39-58; "Norwegian Ecophilosophy and Ecopolitics and their Influence from Buddhism."

${ }^{18}$ Sigmund Kvaløy, "Gjenforeningen med det Ene som gjennomstrømmer all natur" (drawing). In Gunnar Breivik and Haakon Løymo (eds.), Friluftsliv fra Fridtjof Nansen til våre dager (Oslo: Universitetsforlaget, I978), p. I93. 
What form will this new ecophilosophy take? Will it supplant, alter or be absorbed into existing religious theology and become the new ecoreligion that offers the salvation of mankind as a substitute for salvation of the individual; or will it be merely another parameter of human understanding, outside of religion, scientifically based, but recognized for its importance to the future of human society. ${ }^{\text {I9 }}$

Klein was in favor of the last option. To him this was an issue of intellectual hierarchy: science and not religion should be at the core of knowledge. Yet he recognized that the "mass media capitalizing on the public interest in ecology, plus the inexactness of ecology as a science," made his field vulnerable to absorption into existing cultural conceptions and religions. ${ }^{20}$ When Klein wrote his paper ecology was much in the news, both in Norway and in the USA, and the research field's lack of precision was also widely recognized among biologists. What worried Klein was the bending of ecological research in support of what could easily end up as authoritarian religious dogma. "[T]he current ecological movement [is] strongly infused with a 'religious' emotionalism and a revival of vitalism in attitudes toward nature," he claimed. ${ }^{2 \mathrm{I}}$ Moreover:

[S]ome philosophers and ecologist-conservationists have ... become spokesmen for the developing ecoreligion. They argue that the survival of the human species in the face of an impending "eco-crisis" is dependent upon the widespread adoption of a religious humility toward nature. They admittedly are searching for a "panacea for the masses" on the premise that the end (in this case the survival of mankind) justifies the means. Their motivations therefore, while sincere, are pragmatic rather than epistemological. ${ }^{22}$

Næss was the chief target of this criticism as he valued a potential ecoreligion on pragmatic grounds. Klein would have none of it. He also warned against developing a new ecoreligion on epistemological grounds, as Kvaløy suggested. Klein believed that it could easily, like all religions, develop into an "emotional self-righteousness" ideology that would justify and encourage irrational or destructive acts "in the name of piety." 23 Therefore, the idea of fundamentalism developing in the name of the

19 David R. Klein, “The Emerging Ecophilosophy,” unpublished, Feb. 1972, typescript 7 pages, quote p. I, PA. I am grateful to Klein for making the manuscript available. David R. Klein, The Making of an Ecologist, Karen Brewster (ed.) (Fairbanks, Alaska: University of Alaska Press, 2019), 437-56.

${ }^{20}$ Klein, "The Emerging Ecophilosophy," p. I.

${ }^{21}$ Klein, "The Emerging Ecophilosophy," p. 2.

${ }^{22}$ Klein, "The Emerging Ecophilosophy," pp. 3-4.

${ }^{23}$ Klein, "The Emerging Ecophilosophy," p. 4. 
environment and environmental good was the issue at stake here. As Klein said, "One wonders how many Giordano Brunos might be at least figuratively burned at the stake in the name of an ecoreligion." ${ }^{24}$

Instead of an ecoreligion, Klein argued, the philosophers should formulate a new eco-ethics or philosophy with a scientific foundation. Mysterud and Østbye agreed, and they had an impact. Næss, for example, thought Klein's "warning against ecoreligion” was "very relevant!" 25 Two years later he would recall the paper saying that "Klein may be right in his fear that the ecological movement, as any other, will foster some sectarianism and thereby intolerance, arrogance, verbal rituals instead of debate, [and] sentimentality instead of spontaneity." Yet he could not agree with Klein that an ecophilosophy or ecoreligion firmly based on non-violence "would lead to persecution of the ecosophic 'infidel'."26

The ecophilosophers at the Tømte seminar would, in effect, take Klein's warnings to heart, as their subsequent writings would focus on philosophical and not theological arguments. This was not a hard choice for Næss, who wrote about theology for the sole purpose of broadening his audience, while in public appearances Kvaløy would focus on environmental issues and less on his Buddhist beliefs. Yet the inclusive mood of thinking with respect to ethics, beliefs, and religion by ecophilosophers and some ecologists sent important signals to the Christian community. "Ecosophy is a kind of philosophy and not religion," Næss pointed out. "Yet it can easily be given a religious meaning." 27 What that "meaning" entailed would soon be explained by lay churchgoers and an emerging group of eco-theologians.

\section{ECOLOGICAL DEBATE WITHIN THE CHURCH}

The Christian community was not indifferent to the ongoing environmental debate, the Mardøla demonstrations, White's criticisms, or the ecophilosophical activities. Though it is unfeasible to locate all responses, the following passages indicate that reactions from churchgoers varied from flat-out rejection of the relevance of environmentalism to faith, to deep-felt sympathy toward the cause.

${ }^{24}$ Klein, “The Emerging Ecophilosophy,” p. 5.

${ }_{25}$ Næss, Økologi og filosofi, 3rd ed., p. 2 I4.

${ }^{26}$ Næss, Økologi, samfunn og livsstil, 4th ed., p. 2 I I.

27 Næss, Økologi, samfunn og livsstil, 5th ed., p. 278. Milada Blekastad, "Poesi og økologito sider av same sak?" Forskningsnytt, I9, no. 5 (I974), 19-23. 
Among those rejecting environmentalism altogether were both conservative and left-leaning theologians. The way to God, according to conservative theologians, was through prayer, reading of the Scripture, and participation in Church rituals. The fact that population growth was an underlying cause for environmental problems also seemed to contradict the key call in the Bible to "[b]e fruitful, and multiply, and replenish the earth, and subdue it." ${ }^{28}$ The radicals, on the other hand, were worried that nature protection could take attention away from helping the poor. "There is no road from the [natural] world to God," a socialist student of theology argued in 1970. "To arrive at faith in God by studying nature, speculating about the path of the stars or sitting by the Vøringsfossen [waterfall], is according the Christian thinking not only a completely absurd thought, it is also a sin that lead humans away from their original destiny," namely faith in Christ and care for fellow human beings. ${ }^{29}$ Vøringfossen, it is worth noting, was a prime tourist destination in the scenic Norwegian fjords threatened by hydropower development, and it had been the object of romantic longing for at least a century. The idea that admiring the splendor of the waterfall had nothing to do with religion was particularly upsetting to environmentalists who desperately needed support in their (ultimately) failed attempt to save it from destruction.

The orthodox standpoint of both conservative and leftist theologians with respect to nature protection would gradually change. After all, old school churchgoers were also nature goers devoted to outdoor life, an activity that for some represented "a partial return to the state of nature" when humans "went naked in the Garden of Eden, and lived directly from nature's gifts." ${ }^{\circ}$ A growing group of radicals within the Church were also turning their attention to nature protection, as an environmental socialist observed in I97I. ${ }^{3 \mathrm{I}}$ The non-violent demonstration to protect the Mardøla River in the summer of I970, fronted by the ecophilosophers, was admired in a theological journal. ${ }^{32}$ One of the key activists at Mardøla would in the same journal argue that the demonstration was signaling "one of the most exciting watersheds in Western history"

${ }^{28}$ The Bible, Genesis I, 28. Jakob Try, "Befolkningsproblem, matvaresituasjon og kortsynthet," Kirke og kultur, 73 (1968), 326-38.

29 Trond Skard Dokka quoted in Pål Repstad (ed.), Kirken og samfunnet (Stavanger: Nomi Forlag, I970), p. I06.

30 Borchgrevink, "Naturfølelse og naturvern," pp. 360-I.

$3^{\mathrm{I}}$ Bjørn Unneberg, Grønn sosialisme for utkantproletarer (Oslo: Cultura Forlag, 197I), p. 4I.

32 Berit G. Holm, "Ikkevold - teori og praksis," Kirke og kultur, 76 (I97I), 4I I-29. 
between "the literal interpretation of the Jewish command about conquering the earth" and a new "understanding of values" and "protection of life" in nature. "The issue at stake," the activist claimed, was to be found "in the realm of ethics and religion." ${ }^{33}$ The Mardøla experience had given him a feeling of being part of the "the wheel of life" or "the brotherhood with our fellow earth" which meant that "we must give up increasing our [material] wealth" and halter the population growth. ${ }^{34}$ A similar sentiment was expressed by Ole Jensen (I937), a lecturer in philosophy of religion at the University of Århus, Denmark, who visited the University of Oslo in September I97I with the paper, "Pollution is Blasphemy." "We have caught the wrath of the Gods, as we have replaced gratitude with usurpation and exploitation, as we continuously exceed our limits [to growth]." 35 Following White, he argued that unchecked economic growth was an act of hubris, "a gigantic suicidal foolishness," caused by Western Christendom. ${ }^{36}$ As a remedy Jensen pointed to the value of Indigenous religions and Indian mysticism. ${ }^{37}$

Rolf Edberg (I9I 2-97) was one of those who managed to turn Christians on both sides of the Cold War divide toward the environmental cause. He was the Swedish ambassador to Norway who, through a series of books, questioned the technological understanding of the human condition..$^{3}$ As early as I 966, he published a book on the importance of taking better care of the Earth, and a series of popular books on ecology with religious undertones hit the bookstores in the subsequent decade in Norwegian, Swedish, and English. ${ }^{39}$ They were inspired by the ecophilosophy of Kvaløy

33 Jon Godal, "Mardøla-aksjonen og norske bønders vandring til Kongen i København," Kirke og kultur, 76 (I97I), 494-8, quotes pp. 496, 497.

34 Jon Godal, "Om hardingfele og naturvern," Kirke og kultur, 77 (I972), 406-8, quote p. 408 .

35 Ole Jensen, "Teologisk argumentasjon for tesen: Forurensning er blasfemi," Kirke og kultur, 77 (I972), 385-96, quote p. 387 .

${ }^{36}$ Jensen, “Teologisk argumentasjon," p. 386.

37 Ole Jensen, I vakstens vold: økologi og religion (Copenhagen: Fremda, I976). Henning Nørhøj, Moder jord: om kristendom og økologi (Copenhagen: Nyt Nordisk forlag, I977).

${ }^{8}$ Rolf Edberg, “Jordens resurser och den tekniska människan,” Kirke og kultur, 72 (I967), I95-2I I; Et støvgrann som glimter: Ødelegger vi mulighetene for fortsatt liv på jorden? Hans Heiberg (trs.) (Oslo: Aschehoug, 1967). Juel Stubberud, "Rolf Edberg og Norge," in Rolf heter jag (Karlsatd: Föreningen för Värmlandslitteratur, 2000), pp. I I9-26.

39 Rolf Edberg, Spillran av ett moln: Anteckningar i färdaboken (Stockholm, Norstedt, I966); Vid trädets fot: Lekmannafunderingar mot höstlig bakgrund (Stockholm, Norstedt, I97I); Brev till Columbus (Stockholm: Norstedt, I974); The Dream of Kilimanjaro (New York: Pantheon Books, 1976); Tomorrow Will Be Too Late: Dialogue on the Threshold of the Third Millennium (Moscow: Progress Publishers, 1989). 
and Næss, though Edberg could, in the capacity of being an ambassador, not publicly endorse their radicalism. Instead he raised environmental concerns in a non-inflammatory manner, and he mobilized passages from the Bible about humility toward the Creation to make his points..$^{\circ}$

The young feminist Dagny Kaul was another - in comparison to Edberg - more radical churchgoer using ecophilosophy in her theological thinking. Instead of mobilizing distinctions such as "deep" versus "shallow" or "ecological" versus "technocratic" in dividing friends from foes, Kaul introduced in 1973 (for the first time in Norwegian) the distinction of "biocentric" versus "anthropocentric" in talking about understandings of nature. She was inspired by the Presbyterian minister from Minnesota Frederic Elder, who discussed this demarcation at length, first in his MA thesis from Harvard Divinity School completed in 1968 and later in subsequent articles and books. ${ }^{4 \mathrm{I}}$ Using Elder as a point of departure, Kaul argued that anthropocentrism was identical with the exploitative Christian attitude White described, while biocentrism entailed a numinous experience of nature as the Lord's Creation. Seeing nature as a whole through the science of ecology entailed for her not only a deep respect for all living creatures' inherent value, but also an opportunity for renewal of theological ontology that could unite humans with the natural world. ${ }^{42}$ This ontological project was taken quite seriously in alternative Christian circles, such as the Rudolf Steiner School, ${ }^{43}$ and became the center of focus again much later on when Kaul became the first eco-feminist in Norway. ${ }^{44}$ At the Norwegian Parliament the representative for The Christian Democratic Party Toralf Westermoen argued that "ecophilosophy was almost like a religion," a fact that was both problematic and inspiring perspective for people of faith. ${ }^{45}$

$4 \circ$ Åsmund Bjørnstad, "Økologi, etikk og religion - ein samtale med Rolf Edbergs forfatterskap," Kirke og kultur, 88 (1975), 206-I 5.

${ }^{4 I}$ Frederick Elder, "Two modern doctrines of nature," in Donald R. Cutler (ed.), The World Year Book of Religion: The Religious Situation, vol. 2 (London: Evans Brothers, I969), pp. 367-94; Prophecy Concerning Man and Environment, MA thesis (Cambridge, MA: Harvard Divinity School, I968); Crisis in Eden: A Religious Study of Man and Environment (Nashville: Abingdon Press, 1970).

42 Dagny Kaul, "Dilemmaet i moderne naturoppfatning," Norsk teologisk tidsskrift, 74 (I973), I63-8I.

43 Svein Aage Christoffersen, "Biologi og kristendom" (review), Norsk teologisk tidsskrift, 74 (1973), I82. Johannes Hemleben, Biologi og kristendom (Copenhagen: Borgens forlag, I972).

44 Dagny Kaul, "Ecofeminism in the Nordic Countries," Journal of the European Society of Women in Theological Research, 2 (I994), I02-9.

45 Toralf Westermoen in Forhandlinger $i$ Stortinget 538 (May I3, I975), 4I72. 
These different opinions about the importance of ecophilosophy and environmentalism to Christians were signs of a more fundamental change within the Church. To understand how these came about, one has to take a short detour abroad, to Geneva in May I97I, to a key meeting of a study group within the ecumenical World Council of Churches, whose conclusions became important to the Norwegian scene - events that will be discussed in Chapter 7 .

The meeting was about how churches were to respond to the growing environmental movement. It resulted in the statement, "The Global Environment, Responsible Choice, and Social Justice," which was approved by the Council's Executive Committee and submitted to the United Nations Conference on the Human Environment in Stockholm, which met in June 1972. The document was the main contribution from the world's Lutheran communities to the Conference and it aimed at stimulating a religiously informed environmental debate. It stated that "the world around us ... has value in itself" and called for better "stewardship for the Creator" through "a responsible global environmental policy." ${ }^{46}$ Most importantly, the statement encouraged the world's Christians to engage in the environmental movement. The World Student Christian Federation, for example, invited Thomas Sieger Derr, a professor at Smith College in the United States, to expand on the issue, and the result was the widely read Ecology and Human Liberation (1973). ${ }^{47}$ In his review of various Christian responses to the environmental crisis, Derr argued that humans were the guardians of a nature that should not be exploited but cherished as a divine creation. There was a need to limit population growth, he recognized, but in a cautious way and not at the expense of people's natural birthright.

Per Voksø (1923-2002), who had participated at various Council meetings as early as 1948 , followed the activities of the World Council closely. As a lay churchgoer in 1970 he was democratically elected as the leader of the National Council of the Church of Norway, with the power to oversee all its activities. Inspired by the conclusions of the World Council's study group and Derr's book, he saw that the environmental movement raised vital topics for all Christians. "We have been given an

${ }^{46}$ Executive Committee of the World Council of Churches, "The Global Environment, Responsible Choice and Social Justice," The Ecumenical Review, 23 (I97I), 438-42, quote p. 438.

47 Thomas Sieger Derr, Ecology and Human Liberation: A Theological Critique of the Use and Abuse of Our Birthright (Geneva: World Council of Churches, 1973). 
Earth to manage, we are not allowed to destroy it," he claimed. ${ }^{48} \mathrm{He}$ asked the Council's Research Department, along with the Council for Church Collaboration and the Church Academy, to organize a conference on the topic, and this took place at the end of September 1973. This top-down institutional effort to address environmentalism represented a turning point in the history of eco-theology in Norway, as ecology from then on would gradually move from the periphery to the center stage of Church debate. Though the individual papers at the conference did not represent the views of the Church, the conference sent a clear message from the Church's executive body about the need to address environmentalism.

The conference began with papers by scholars from outside the Church who, in effect, were invited to set the agenda. The ecologist Oddvar Skre, for example, presented his latest research on acid rain, and concluded that "the ideology of economic growth should be replaced by a society in ecological equilibrium" 49 Likewise, Olsen suggested an "eco-political minimum program" for the Church based on ecological equilibrium principles. ${ }^{5 \circ}$ Others pointed to the international legal and political ramifications of the eco-crisis. ${ }^{\text {I }}$

The theologians responded with papers about the culture of materialism in an industrialized society and the need to respect the integrity of the Lord's Creation. Within The Norwegian School of Theology, for example, the opponents of capitalism favored greater social responsibility among Christians, especially toward the poor. Environmental problems were the result of private ownership and exploitation of land by people who did not recognize that humans had nature on loan, one of them argued, as eco-centered faith was not the way forward. "Don't let the Church's preachers become [natural] resource and environmental

${ }^{8}$ Per Voksø, "Innledning,” in Per Voksø (eds.), Mennesket og miljøet (Oslo: Kirkerådets utvalg for forsking og utredning, Luther forlag, I975), pp. 7-IO, quote p. 7.

49 Oddvar Skre, "Mennesket og naturmiljøet: Ressursfordeling og ressursbehov i dag og i morgen," in Per Voksø (ed.), Mennesket og miljøet (Oslo: Kirkerådets utvalg for forsking og utredning, Luther forlag, I975), pp. I I-35, quote p. 29.

${ }^{\circ}$ Harald Olsen, "Utkast til et økopolitisk program," in Per Voksø (ed.), Mennesket og miljøet (Oslo: Kirkerådets utvalg for forsking og utredning, Luther forlag, 1975), pp. $78-96$, quote p. 78 .

${ }^{51}$ Erik Nord, “Økokrisens internasjonale perspektiver," in Per Voksø (ed.), Mennesket og miljøet (Oslo: Kirkerådets utvalg for forsking og utredning, Luther forlag, 1975), pp. 50-5. Kjell Skjelsbæk, "Økokrisen som en utfordring til velferdssamfunnets ideologi og struktur,” in Per Voksø (ed.), Mennesket og miljøet (Oslo: Kirkerådets utvalg for forsking og utredning, Luther forlag, I975), pp. 56-70. 
parsons!" he warned the Council, it would only lead to a "re-mystification of nature which is in dispute with the biblical doctrine of Creation." ${ }^{2}$ The leading lay-Christian intellectual raised similar concerns in a "eco-political" plea for human managerial responsibility for an "Earth belonging to the Lord." 53 A lecturer in history of religion at the University of Bergen, Gaute Gunleiksrud (1936-2008), took a stand against White's thesis. Since one could not blame theology for the abuse of nature, he argued, the solution to the eco-crisis should consequently not come from the Church: "The belief that the Kingdom of God has become near through Christ is something totally different than working to protect and improve the old world ... One could benefit from being careful with placing ecology and Christian belief together." ${ }^{54}$ Nevertheless, Gunleiksrud thought the Church should embrace environmentalism on pragmatic grounds. That ecophilosophers publicly embraced "ecological models in pantheistic (especially Indian) religiosity [and] myths about Mother Earth" was of concern in an increasingly secularized society, and the Church should "in this situation of urgency" be willing "to talk about God when we normally would talk about humans and their ethical responsibility" toward the Creation. ${ }^{55}$

These comments illustrate a dilemma: the belief in salvation and the coming of Christ had nothing to do with the environmental state of the material world. Yet the pietist Church had always been critical of the consumerism of industrial society. Caring for the earth as God's Creation could, perhaps, curb materialism and prepare the soul. Besides, it was clear to all by 1973 that environmentalism was a major moral force within society, especially among the young. The Church would have to respond by emphasizing human managerial responsibility. This, at least, was the argument of Jens Gabriel Hauge (I927-2005), who was a professor of biochemistry at the Norwegian Veterinary School and leader of the Council's Research Department. We must be "society's watchdog,"

52 Torleiv Austad, "Kirkens medansvar for den rådende sosiale praksis," in Per Voksø (ed.), Mennesket og miljøet (Oslo: Kirkerådets utvalg for forsking og utredning, Luther forlag, I975), pp. 36-49, quotes pp. 43, 47.

53 Jens Wisløff, "Utkast til et økopolitisk program," in Per Voksø (ed.), Mennesket og miliøet (Oslo: Kirkerådets utvalg for forsking og utredning, Luther forlag, 1975), pp. 7 I-7, quote p. 75.

54 Gaute Gunleiksrud, "Kristne perspektiver på økologi: om skapertro, menneskesyn og forvalteransvar," in Per Voksø (ed.), Mennesket og miljøet (Oslo: Kirkerådets utvalg for forsking og utredning, Luther forlag, I975), pp. 97-I I I, quote p. 98.

55 Gunleiksrud, “Kristne perspektiver på økologi,” p. IоI. 
he argued, and make sure "political decisions are made according to the Bible's managerial thinking." $" 56$

\section{ECORELIGION ON THE SYLLABUS}

In the winter of I974 an article about the emerging new ecoreligion appeared on the syllabus for a mandatory core Examen philosophicum course at the University of Oslo. It was written by Gunnar Breivik (b. I943), a keen follower of the ecophilosophical debate. It is worth discussing this item in some detail as it indicates an important shift from intramural theological debate to a more missionary trend on the behalf of ecoreligion toward students.

Breivik was the son of Birgir Breivik (I9I2-96), who was a major mover within leksmannsbevegelsen (the lay-pietist movement). The members of the leksmannsbevegelsen constituted some of the most committed members of the Church. Birgir Breivik was an elected member of the Norwegian Parliament (1965-70) as a politician of The Christian Democratic Party, and the Assistant General Secretary (1965-70) and then General Secretary (1970-82) for the Norwegian Lutheran Mission. The lay-pietist movement he represented had its stronghold among peasants and fishermen on the western coast of Norway where the Breivik family was from, a place where Lutheran faith went hand in hand with community activism, and there was much skepticism toward centralized politics, alcohol, and materialism. ${ }^{57}$

Gunnar Breivik followed the path of his father in describing himself as a "new-pietist" from the lay church movement, which had "conversion and mission" at its core. ${ }^{58} \mathrm{He}$ graduated from The Norwegian School of Theology in 1969 with philosophy as an intermediate subject. The chief aim of the School of Theology, it is worth noting, was to educate vicars to go on to work in local parishes around Norway. It was privately funded and known to take a more conservative stand on religious issues in comparison to the more research-oriented Faculty of Theology at the

${ }^{56}$ Jens Gabriel Hauge, "Kirkens engasjement i økokrisen: Oljeuttalelsen som vedlegg," in Per Voksø (ed.), Mennesket og miliøet (Oslo: Kirkerådets utvalg for forsking og utredning, Luther forlag, I975), pp. II3-20, quote p. II6.

57 Geir Gundersen, "Lekmannsrørsla og klassekampen," Ung teologi, 5 (I97I), 47-6I.

${ }^{58}$ Gunnar Breivik, "Teologi og politikk," in Pål Repstad (ed.), Kirken og samfunnet (Stavanger: Nomi Forlag, I970), pp. I08-20, quote p. I I2; "Biografiske opplysninger," in Vegard Fusche Moe and Sigmund Loland (eds.), I bevegelse: et festskrift til Gunnar Breivik på hans 60-årsdag (Oslo: Gyldendal, 2003), 23 I-40. 
University of Oslo. The School did not, for example, have the right to issue a Doctoral degree, but used an exchange program to pass especially talented students to its counterpart, the Faculty of Protestant Theology at the University of Tübingen in Germany.

Breivik was one of the scholarship recipients who thus came to study at Tübingen for the academic year of 1970-7I. He earned the grant by submitting three articles on Martin Heidegger, theology, and politics respectively, which must have impressed the grant committee. Among the students at the competing Faculty of Theology there was, at the time, a vocal group of radical students questioning whether or not a political revolution in God's name was justified in view of the ongoing Vietnam War, poverty, and other social injustices. ${ }^{59}$ Breivik attacked them headon: "God's kingdom breaks in, it cannot be established by people through political and social revolution and upheaval." $" 60$ What worried him was the uncritical theological adaptation of the social and political sciences. "Society and politics are situated in the periphery," Breivik argued, while "prophetic-critical character" of Christendom was at the center of belief. ${ }^{6 \mathrm{I}} \mathrm{He}$ saw in Heidegger's philosophy a potential to reengage a unified and consistent theology that harkened back to the unity and purity of its Medieval and scriptural origins. "Perhaps after a while we will be in a position to practice theology within a larger dimension and thus the history will open up for us," he envisioned. ${ }^{62}$ It was this longing for theological unity that later reemerged in Breivik's eco-theological writings about pre-industrial Christianity and the purity of nature as a source of religious reflection.

After Breivik's graduate studies in Tübingen had ended in I97I (without a degree), he enrolled at the Norwegian School of Sport Sciences where Faarlund taught his ecophilosophy of outdoor life class. Breivik must have been taken in by ecophilosophy and the environmental movement, as he would eventually abandon the idea of becoming a vicar in favor of a life more oriented to the outdoors. Outdoor life represented the way forward for a new society reconciled with nature. "Outdoor life is politics today," he would say, as it was on issues related to this lifestyle

59 Andreas Skartvet (ed.), Revolusjon i Guds namn? (Oslo: Samlaget, I968). Nils Johan Lavik and Jardar Seim (eds.), Deilig er jorden? Ti innlegg om demokrati, revolusjon og kristendom (Oslo: Pax, 1969).

${ }^{60}$ Breivik, "Teologi og politikk," p. I Iо.

${ }_{61}$ Breivik, "Teologi og politikk," pp. I I3, I20.

${ }^{62}$ Gunnar Breivik, "Om teologiens opprinnelse," Norsk teologisk tidsskrift, 7I (I970), I76-9I, quote p. I90; "Heidegger og teologien," Ung teologi, 3 (I970), 8 I-92. 
and its "fights for nature" that principles of ecology would be truly realized. ${ }^{63}$ At the School he took an intermediate degree in 1973, after which Breivik worked as a high school teacher in Oslo while finishing up his Master of Arts thesis in $1975 .{ }^{64}$

The debates around ecoreligion were largely an internal affair among theologians until the winter of I974. A I973 reform of the University of Oslo's core courses Examen philosophicum added an essay by Breivik into the syllabus so that it became mandatory reading for a substantial number of students. It was for the Nature and Humans course discussed in Chapter 5, which contained a series of articles by other key academic environmentalists from Norway. This was the first time that not only ecoreligion but also ecophilosophical issues in general became the topic of tricky exam questions that students had to answer in order to continue their studies in any field at the University of Oslo.

A head-on attack on Protestant theology for its exclusion of nature was at the core of Breivik's article. "Nature as a category does not exist" in the theological disciplines, he argued. ${ }^{65}$ Christian ethics was only concerned with humans and society, he claimed, and if nature appeared in moral discussions it was only as a resource for human welfare. Based on this criticism, which echoed White's paper, Breivik launched his own alternative ecological interpretation of Genesis with a focus on humans as gardeners of God's Creation. To Breivik "eco-philosophy, eco-life, ecopolitics" signified a radical turn toward trying to serve nature "in His honor" as Adam and Eve once did as gardeners in Paradise. ${ }^{66}$ It is naive to expect a return to Paradise by our own will: "Yet it is not naivety trying to adapt the basic attitude of the gardener. It is not naivety to begin to collaborate with nature, built on the insights of the ecological laws. It is not naivety to try to restrict the Earth's population. It is we who began the fight against nature. It is we that have to change. ${ }^{67}$ Breivik pointed to a series of passages from the Bible, including words of wisdom from the Psalms to support his claims. The Bible said that humans should "replenish the earth, and subdue it: and have dominion over the fish of the sea,

${ }^{63}$ Gunnar Breivik, "Friluftsliv: en vei til et nytt samfunn," Mestre fjellet, 6 (I973), 23, 39.

${ }^{64}$ Gunnar Breivik, Idrettens filosofi, MA thesis (Oslo: The Norwegian School of Sport Sciences, I975).

${ }^{65}$ Breivik, "Læren om Gud og det store huset," p. I. Breivik argued against views held by Peter Wilhelm Bøckman, Liv, fellesskap, tjeneste: en kristen etikk (Oslo: Universitetsforlaget, I970), and Per Øverland, Kristen etikk (Oslo: Lunde, I970).

${ }^{66}$ Breivik, "Læren om Gud og det store huset," p. 6.

${ }^{67}$ Breivik, "Læren om Gud og det store huset," p. I3. 
and over the fowl of the air, and over every living thing that moveth upon the earth." ${ }^{68}$ Yet Breivik argued that this should be read with a focus on passages which emphasized human humility toward Creation: "When I consider thy heavens, the work of thy fingers, the moon and the stars, which thou hast ordained; What is man, that thou art mindful of him? and the son of man, that thou visitest him?" 69 Thus, the article was an exegesis of quotes from the Bible, which could support humility toward nature and an ethics of gardening God's estate in His honor. What students reading the article were meant to conclude was that the current industrial exploitation of Creation was not in honor of God, and that true Christians therefore had to change their lifestyle so that the original ecological harmony of nature could be restored. Those who did not get the point would risk failing their exams and, as a consequence, have to leave campus.

Breivik's article and its status on the syllabus of the University core course did not please conservative theologians. The chief among them was Inge Lønning (1938-20I3). He was a graduate student enrolled at the Department of Theology when Breivik was studying at The School of Theology, who went on to become a professor of theology at the University of Oslo in I97I, and subsequently the chief editor of the leading journal Kirke og kultur (Church and Culture). He was also an active member of the Conservative Party and brother of the Bishop of Borg (a key diocese that surrounds Oslo). Should "theology be the maid of ecosophy?" he wondered, noting that "the tendency to offer the service of theology within the ecophilosophical discipline [was] advancing rapidly." 70 Lønning could accept Næss's "arbitrary" use of the Bible to "support an ecophilosophical/political program" as he was not religious. Breivik, on the other hand, was "a theologian by profession" and his article was "partly official," as it was the only theological text on the entire Examen philosophicum syllabus. ${ }^{7 \mathrm{I}}$ His article was thus, in effect, the first meeting that potential students would have with the discipline of theology, though freshmen with a religious bent could opt out of the "Nature and Humans" seminar and replace it with one of the other courses. Lønning believed that, by arguing that nature as a category was excluded, Breivik gave "a grossly misleading picture of the

68 The Bible, Genesis I, 28. ${ }^{69}$ The Bible, Psalm 8, 3-4.

70 Inge Lønning, “Teologien som økofilosofiens tjenestepike?” Kirke og kultur, 80 (I975), 237-8, quote p. 237.

${ }^{71}$ Lønning, “Teologien som økofilosofiens tjenestepike?” p. 237. 
history of theology," and that Breivik had projected his "social gospel" of saving the environment onto the "natural gospel" of the Bible. The article was "not acceptable" as a foundation on which students were supposed to build their academic career, Lønning argued "with a heavy underlining." $7^{2}$

The criticism would not stop Breivik, who, during this time, abandoned his theological career in favor of his studies with Faarlund at the School of Sport Sciences. In his entry for the second edition of the "Nature and Humans" reader, he maintained his eco-religious views. "The lifestyle today of the industrial human being is not in God's honor," he argued, setting his hopes on any religion that recognized "equality in the biosphere." 73

Putting ecoreligion on the syllabus and thus in the minds of young students became an important task for Breivik in the subsequent years. The message that high school students were to learn, for example, was that there were two conflicting Christian models on how to deal with nature: one emphasizing a human right for exploitation of an obedient nature, and another with equality and equilibrium within the environment as the focal point. The first model had led to the eco-crisis, while the second promised a way out of it. He quoted the Book of Ecclesiastes as evidence for the claim that humans did not have a higher moral status than other species: "For that which befalleth the sons of men befalleth beasts; even one thing befalleth them: as the one dieth, so dieth the other; yea, they have all one breath; so that a man hath no preeminence above a beast." The guiding principle Christian students were to draw from his analysis was "solidarity within the biosphere, management in honor of God." 74 As Breivik saw it, cleaning up pollution was a penitential exercise for human sins toward Him and His Creation, and consequently an important task for young Christians.

\section{THE GREENING OF THE CHURCH}

The debate about ecoreligion would cause tension as well as optimism among believers with respect to a renewal of the Church. The idea that

${ }^{22}$ Lønning, “Teologien som økofilosofiens tjenestepike?” p. 238.

73 Gunnar Breivik, "Religion, livsform og natur," in Paul Hofseth and Arne Vinje (eds.), Økologi: Økofilosofi (Oslo: Gyldendal, I975), 82-95, quotes pp. 85, 90.

74 The Bible, Ecclesiastes 3, 19. Gunnar Breivik, "Forurensning og naturvern," in Lars Østnor (ed.), Nestekjaerlighet i samfunnet: Sosialetisk spørsmål i kristent lys (Oslo: Luther Forlag, I975), pp. I20-32, quotes pp. I30, I3 I. 
human population growth was one of the prime reasons for the eco-crisis represented a challenge to members of the Church who saw the birth of a human being to be something positive. ${ }^{75}$ Another problem was that the high moral ground of the environmentalists made others look dissolute, as the lifestyle demands for right ecological living were high and the questioning of industrialized society was radical. It was not easy, even for the devoted, to live according to eco-religious and philosophical principles. These issues and other similar issues threatened to push different types of environmental believers apart:

Some believe that the time is ripe to move from words to action and find a way of life that is more in agreement with Christian belief. Others can't break out and must find content with small steps. Still others must stay within the old structure as they have necessary political work to do. The situation is too critical for letting these groups be played up against each other. The body of Christ is one, but has many parts. ${ }^{76}$

This call for unity and respect for each other, made by Gunleiksrud in I975, may serve as evidence of a Church divided on how to incorporate ecological perspectives into a theological framework.

These tensions would persist for years, though subsequent events indicate that the Church as a whole gradually moved toward ecotheology. A sign of this shift came in 1978 when the Council of the Church of Norway's Research Department arranged another conference to address the ecological crisis. At the time a major new hydropower development on the Alta-Kautokeino River was in the news, and environmentalism was on the political agenda, especially on the left side of the Cold War political divide. The Church sought to nurture support from both sides. For the 1978 meeting, the eco-crisis represented an opportunity to be radical and progressive within acceptable socio-political borders.

The event was organized by a Christian biologist, who argued that Christians should take a stand against economic growth and also promote "changes in basic attitudes" to nature. ${ }^{77}$ It was important for the

75 Jens Gabriel Hauge, "Kirkens Verdensråd og befolkningsproblemene," Kirke og kultur, 80 (1975), 76-85. Ola Rokkones, "Behovet for en norsk befolkningspolitikk," Kirke og kultur, 80 (1975), 92-гог. Erling Berge, "Befolkning og befolkningspolitikk," Kirke og kultur, 80 (1975), I02-10.

${ }^{6}$ Gaute Gunleiksrud, “Om å være kristen i et i-land i en u- og øko-tid,” Kirke og kultur, 80 (1975), I93-205, quote p. 205.

77 Harald Olsen, "Forord," in Harald Olsen (ed.), Mot et samfunn i likevekt: fra de nordiske kirkers arbeid med ressurs- og miljøspørsmål (Oslo: Land og Kirke, 1978), pp. 7-9, quote p. 8. 
Church to expose "idols of the syndrome of growth and false paradise," another conference participant argued. ${ }^{78}$ Environmentalism framed as protection of Creation could offer a way out of materialism for congregations. The Church should take its share of the blame for the "Babylon" of capitalism and exploitation of nature of modern society, and work to nurture an ecological way of thinking. ${ }^{79}$ These and similar statements were radical, even revolutionary, but not socialist. If anything, they represented traditional lay-pietism in new environmental clothing.

At the heart of the discussion was a paper by Breivik, which may have been his first appearance within a sanctioned research conference by the Church. Since 1975 he had been the first professor of outdoor-life at the Norwegian School of Sport Sciences, where he taught the art of "free-air life," a discipline based on the teachings of Faarlund, Kvaløy, and Næss. ${ }^{80}$ At the conference he began with a head-on attack on Lutheran ecclesia: it had been "sleeping and a hanger-on, as e.g. in Germany during the last war," with respect to exploitation of nature. ${ }^{8 \mathrm{I}}$ As a remedy he rehearsed his earlier argument about managing the Earth in honor of God as gardeners of his Creation. What was new was Breivik's emphasis on the necessity of an eco-centric ethic, and he suggested several reinterpretations of key scriptural passages to make his case: "In the beginning God created the heaven and the earth," said the Bible, which for Breivik meant that "[e]very species and the whole nature have value in themselves. They are thus not only valuable as food or tools for humans. Nature has inherent value." 82 If the Earth were created by God, then He is its owner, Breivik argued, and humans should consider themselves as guests who are visiting Him and as living on land that is not theirs. The debated passage in Genesis where God tells humans to "[b]e fruitful, and multiply, and replenish the earth, and subdue it," was, according to Breivik, not God giving humans carte blanche to exploit nature, but instead, a call to "fill in an assigned 'ecological space'." ${ }^{83} \mathrm{He}$ also reminded the audience that

${ }^{78}$ Jonas O. Jonson, "Skapelsen: Frelsens sakrament," in Harald Olsen (ed.), Mot et samfunn i likevekt (Oslo: Land og Kirke, I978), pp. I 24-37, quote p. I35.

79 Gaute Gunleiksrud, "Vektsamfunnets krise og kirkens evangelium," in Harald Olsen (eds.), Mot et samfunn i likevekt (Oslo: Land og Kirke, I978), pp. I38-54, quote p. I40.

${ }^{80}$ Gunnar Breivik, Friluftsliv: noen filosofiske og pedagogiske aspekter (Oslo: Norges Idrettshøgskole, I979). Gunnar Breivik and Haakon Løymo (eds.), Friluftsliv fra Fridtjof Nansen til våre dager (Oslo: Universitetsforlaget, I978).

${ }^{81}$ Gunnar Breivik, "Likevektssamfunnet - et teologisk vurdering," in Mot et samfunn i likevekt, Harald Olsen (ed.) (Oslo: Land og Kirke, I978), pp. I08-23, quote p. Io8.

82 The Bible, Genesis I, I. Breivik, "Likevektssamfunnet," p. I20.

${ }^{83}$ The Bible, Genesis I, 28. Breivik, "Likevektssamfunnet,” p. I 20. 
trying "to imitate [the life of] Christ implied a simple life in frugality," which was incompatible with the consumerism of modern society. ${ }^{84}$

Breivik made an impact. The conclusion of the conference was inspired directly by his statements and came in the form of an "ecclesiastical plan of action" to mobilize the Bishops through the Church National Council to further research, organize, and implement an eco-ethic within the entire Church. ${ }^{85}$ The first step was to assign the anthology from the conference as a textbook. It was used well into the early I 980 os by the chief organizer of non-academic religious training, the Norwegian Council for Christian Studies, who provided funding for any study group willing to read and discuss the anthology.

Young students of theology would not uncritically adopt the ecoreligion of Breivik and his ecophilosophical partisans. Yet their challenges led to new readings of the Scripture that emphasized human modesty and respect for Creation. ${ }^{86}$ Breivik himself would also stress that the inherent value of nature and its species were upheld by God, and that humans were housekeepers in nature's household manifesting His goodness. ${ }^{87}$ As one young scholar put it: "[t] hat Nature has value independently of humans does not mean that it is holy." 88 Thus, ecoreligion did not imply any pantheism or worship of nature itself. It implied instead a religiously informed ecological housekeeping on God's behalf, and since God's demands were omnipresent, young intellectual theologians consequently began addressing practical issues such as the use of energy to heat churches and clerical offices. ${ }^{89}$

${ }^{84}$ Breivik, "Likevektssamfunnet," p. I22.

${ }_{5}$ Svein Takle, "Momenter for et kirkelig handlingsprogram," in Harald Olsen (ed.), Mot et samfunn i likevekt (Oslo: Land og Kirke, I978), pp. I 55-63.

${ }^{86}$ Roar Strømme, Økologi og teologi: tankar om ei kristen naturforståing innfor den økologiske krisa, MA thesis (Oslo: Menighetsfakultetet, I978); “Teologien i møte med øko-krisa," Ung teologi, I 2 (I979), I-II. Olav Øygard, Preken $i$ møte med den økologiske krise, MA thesis (Oslo: Menighetsfakultetet, I98I). Magne Fitjar, Økologi og verdi hos Arne Noess og Ole Jensen: semesteroppgave i miljøfag (Bergen: Department of Geography, I983). Jan-Olav Henriksen, Mennesket og naturen: etiske og religionsfilosofiske perspektiver på naturen og økokrisen (Oslo: Menighetsfakultetet, I99I).

87 Gunnar Breivik, "Kristen tro og natur-forståelse," Kirke og kultur, 84 (1979), 345-52. Trond Berg Eriksen, "Naturen som appellinstans," Kirke og kultur, 79 (1974), 293-6.

${ }^{88}$ Per Tangaard, Energi over alle grenser: kristent livssyn og forvaltning av ressurser (Oslo: Credo, I983), I4.

89 Knut Hofstad, "Energibruk - et etisk problem?" Kirke og kultur, 83 (1978), 297-300. Inger Heiberg, "Energibruk - et etisk problem?" Kirke og kultur, 83 (I978), 445. Roar Mjelva, "Termodynamikkens 2. hovedsetning som etisk motivasjon," Kirke og kultur, 83 (I978), 445-6. 
To mobilize the young, scholars interested in ecoreligion tried to change both the high school syllabi for both science and religious studies. All high school students in Norway had to take exams in Christianity in addition to biology and other sciences. The fact that non-believers, Jews, and an increasing population of Muslim immigrants had to study Christianity (often taught by practicing Christians) was a topic of heated public debate. The attempt to include ecoreligion in the curriculum should be understood in this context, as a way of addressing pressing moral issues relevant to all peoples of the world. The biology syllabus was also under public scrutiny in the early I980s for failing to address topics of current interest, such as genetics and environmentalism. The attempt to move ecoreligion into the biology curriculum should also be understood in this context, as a response to science teachers explaining human social behavior and environmental concerns in reductionist language. ${ }^{90}$ Hauge thought religion should be introduced in the teaching of evolution as this was a sign of God's creativity in action that would mobilize students' respect. ${ }^{9 \mathrm{I}}$ To this argument theologians replied that God was the Creator of the world's ecology, and that students should learn to take better care of it. ${ }^{92}$ Though the ecologists did not generally agree with the Christian gospel, Breivik believed it was important to nurture a reciprocal relationship between science and Christianity classes. ${ }^{93}$ One should fill schoolbooks about science and religion with the new ecological reading of the Bible, he argued. ${ }^{94}$

The call for a new eco-theology in Norway began in the early I970s with students calling for the inclusion of concern for nature in religious

${ }^{90}$ Lars Viggo Berntsen, “Menneskesynet i biologilærebøker i skolen,” in Peder Borgen (ed.), Mennesket og naturen i kristendom og naturvitenskap (Trondheim: Tapir, I980), pp. 58-IO4.

${ }^{9}$ Jens Gabriel Hauge, “Mennesket og naturen fra naturvitenskaplig syn,” in Mennesket og naturen $i$ kristendom og naturvitenskap (Trondheim: Tapir, I980), pp. 9-28.

${ }^{22}$ Dagfinn Rian, "Mennesket og naturen i det Gamle Testamentet," in Mennesket og naturen $i$ kristendom og naturvitenskap (Trondheim: Tapir, I980), pp. 29-42. Peder Borgen, "Helbredelsesundere i det Nye Testemente: Noen synspunkter," in Mennesket og naturen i kristendom og naturvitenskap (Trondheim: Tapir, I980), pp. 43-64. Peter Wilhelm Bøckman, "Synet på mennesket og naturen i kristen systematikk," in Mennesket og naturen i kristendom og naturvitenskap (Trondheim: Tapir, I980), pp. 65-84. Peder Borgen (ed), Miljøkrise og verdivalg: miljøkrisen $i$ kristent perspektiv og som utfordring $i$ samfunn og skole (Trondheim: Tapir, I99I).

93 Gunnar Breivik, "Menneskets plass og funksjon i naturen i følge kristendommen og den økologiske tenkning: en sammenlignende og kritisk analyse," in Mennesket og naturen i kristendom og naturvitenskap (Trondheim: Tapir, I980), pp. I05-27.

94 Gunnar Breivik, “Teologi og økologi,” Prismet, 3 I ( I980), 4-7. 
debate, and ended a decade later with an equally forceful plea for telling students about ecoreligion in religious as well as science textbooks. The ecological debate promised not only a renewal of Lutheran pietism and therefore of the Church, but also a renewed focus on caring for the Creation. The next chapter will continue discussing how religion also came to frame the thinking of those who were antagonistic to Deep Ecology. It is a story of how a Norwegian environmentalist came to bring ecological concerns and the quest for sustainability abroad to the World Council of Churches. 